\title{
Uji Tanaman Padi Hasil Persilangan Varietas Lokal dengan IRBB-27 terhadap Pertumbuhan dan Ketahanan Hawar Daun Bakteri
}

\section{(Test results of the rice crops of local Varieties with Intersecting IRBB-27 against the growth and resistance of Bacterial leaf blight)}

\author{
Nurdin $^{1}$, Cut Nur Ichsan ${ }^{1}$, Bakhtiar ${ }^{1}$ \\ Program Studi Agroteknologi, Fakultas Pertanian, Universitas Syiah Kuala Banda \\ Aceh - Indonesia \\ Jln. Hasan Krueng Kalee No. 3 Kopelma Darussalam, Banda Aceh \\ E-mail : nurdinsiudin@gmail.com, Kode Pos. 23111
}

\begin{abstract}
Abstrak. Penurunan hasil produksi padi disebabkan beberapa faktor salah satunya adalah penyakit hawar daun bakteri (HDB). Penyakit HDB yang disebabkan oleh Xanthomonas oryzae pv. oryzae $(X o o)$. Penelitian ini bertujuan untuk mengetahui pertumbuhan dan ketahanan tanaman padi (Oryza sativa L.) hasil persilangan antara genotipe lokal dan IRBB-27 terhadap Hawar Daun Bakteri. Penelitian ini menggunakan Rancang Acak Lengkap (RAL) non faktorial dengan perlakuan genotipe dan 5 taraf diulang sebanyak 5 kali sehingga diperoleh 25 satuan percobaan. Setiap satuan prcobaan terdiri 3 tanaman sehingga total tanaman yang diamati yaitu 75 tanaman. Genotipe padi yang digunakan pada penelitian ini adalah Sigupai, Sikuneng, IRBB-27, F1 (Sg/IRBB-27) dan F1 (Sk/IRBB-27). Hasil penelitian menunjukkan bahwa padi Sg/IRBB-27 dan Sk/IRBB-27 tahan terhadap hawar daun bakteri. Lesio terpendek dijumpai pada genotipe F1 (Sg/IRBB-27) yaitu $0,34 \mathrm{~cm}$ pada $14 \mathrm{HSI}$. Sedangkan persentase rata-rata intensitas serangan terendah dijumpai pada F1 (Sg/IRBB-27) yaitu 0,49 \%. Tanaman Sg/IRBB-27 dan Sk/IRBB-27 lebih tinggi jika dibandingkan dengan genotipe IRBB-27. Tanaman Sg/IRBB-27 dan Sk/IRBB-27 lebih tinggi jika dibandingkan dengan genotipe IRBB-27. F1 (Sk/IRBB-27) memiliki rata-rata tinggi tanaman mencapai 145,93 cm, sedangkan F1 (Sg/IRBB-27) rata-rata tinggi tanaman 142,40 $\mathrm{cm}$ ini menunjukkan bahwa hasil kedua persilangan belum memiliki tinggi tanaman padi yang ideal yaitu 90-100 cm.
\end{abstract}

Kata kunci : Pertumbuhan, Ketahanan, Padi, Xanthomonas oryzae pv. oryzae.

\begin{abstract}
The decrease in rice production results due to a number of factors one of which is a bacterial leaf blight disease (HDB). The disease caused by the bacterium Xanthomonas HDB oryzae pv. oryzae (Xoo). This research aims to know the growth and resistance of rice plant (Oryza sativa 1.) yield a cross between genotyping and local IRBB-27 against Bacterial leaf blight. This study used a Randomized Complete Design (RCD) non factorial with genotype and treatment 5 extent repeated as much as 5 times so acquired 25 units of the experiment. Each unit consists of 3 prcobaan the plant so that the total plant observed i.e. 75 plants. Genotype of rice used in this research is Sigupai, Sikuneng, F1-27, IRBB (Sg/IRBB-27) and F1 (Sk/IRBB-27). The results showed that rice $\mathrm{Sg} / \mathrm{IRBB}-27 \mathrm{Sk} / 27-\mathrm{IRBB}$ resistant to bacterial leaf blight. The shortest Lesio found on genotyping the F1 (Sg/IRBB-27) namely $0.34 \mathrm{~cm}$ on $14 \mathrm{HSI}$. While the percentage of average intensity of attack the lowest found in F1 (Sg/IRBB-27) namely 0.49\%. Plant Sg/IRBB-27 Sk/IRBB-27 higher if compared to genotype IRBB-27. Plant Sg/IRBB-27 Sk/IRBB-27 higher if compared to genotype IRBB-27. F1 (Sk/IRBB-27) have an average height plants reach $145.93 \mathrm{~cm}$, whereas F1 (Sg/IRBB-27) average height plants $142.40 \mathrm{~cm}$ indicates that the results of the two intersecting high rice plant has not had the ideal that is $90-100 \mathrm{~cm}$.
\end{abstract}

Keywords: Growth, resilience, rice, the bacterium Xanthomonas oryzae pv. oryzae.

Corresponding author: nurdinsiudin@ gmail.com

JIM Pertanian Unsyiah - AGT, Vol. 1, No. 1, November 2016: 227-238 


\section{PENDAHULUAN}

Padi merupakan komoditas utama sebagai pangan di Indonesia mengingat bahwa makanan pokok di Indonesia adalah beras, maka padi merupakan komoditi yang bernilai sangat tinggi baik dari segi sosial, politik maupun ekonomi. Produksi padi di Indonesia secara nasional belum mencukupi kebutuhan pangan walaupun sudah banyak dilakukan kebijakan dalam meningkatkan produksi padi (Sudaryanto et al., 2006). Penurunan hasil produksi padi disebabkan beberapa faktor salah satunya adalah penyakit hawar daun bakteri (HDB) (Triny et al., 2011).

Penyakit HDB yang disebabkan oleh bakteri Xanthomonas oryzae pv. oryzae (Xoo) merupakan salah satu penyakit utama tanaman padi baik di Indonesia maupun negara-negara penghasil padi lainnya di Asia (Nayak et al., 2008). Penyakit hawar daun bakteri (HDB) tercatat sebagai salah satu faktor pembatas untuk peningkatan produksi padi (CAB International, 2005; Iyer Pascuzzi, 2007), yang dapat menurunkan hasil produksi padi 30-40\% (Kadir et al., 2007; Wibowo, 2002) dan menurunkan mutu beras yang dihasilkan (Wibowo, 2002).

Upaya peningkatan produksi beras di Indonesia telah banyak dilakukan oleh pemerintah salah satunya adalah dengan cara merakit varietas baru. Perakitan varietas baru dapat dilakukan dengan cara persilangan antara varietas yang memiliki gen resisten dengan varietas yang tidak tahan terhadap HDB sehingga menghasilkan tanaman yang diharapkan (Winandari et al., 2014).

Persilangan merupakan salah satu cara untuk mendapatkan atau memperbesar keragaman genetik baru dari suatu komoditi yang dapat dilalui dengan perpaduan sifat-sifat dari suatu tetua, untuk mendapatkan varietas baru yang diharapkan. Tetua yang biasanya digunakan dalam persilangan adalah varietas lokal karena memiliki sifat tahan terhadap cekaman biotik maupun abiotik (Sitaresmi et al., 2013).

Kelebihan padi genotipe IRBB-27 memiliki gen yang tahan terhadap penyakit hawar daun bakteri (HDB). Sedangkan kekurangan dari padi genotipe IRBB-27 adalah hanya dikontrol oleh satu gen sehingga harus dilakukan perakitan keragaman gen baru yang ada pada tanaman padi. Bakteri hawar daun mempunyai banyak strain dan pulasinya dapat bergeser dari satu strain ke strain yang lain. Akibat penggeseran ini genotipe padi yang awalnya tahan dapat berubah menjadi peka tehadap HDB sehingga perlu dilakukan perakitan keragaman gen baru yang ada pada tanaman padi (Tasliah, 2012).

Berdasarkan pemikiran tersebut di atas, maka perlu dilakukan penelitian secara lebih mendalam sehubungan dengan hasil persilangan tanaman padi antara varietas lokal dengan varietas IRBB-27 dan bagaimana tingkat ketahanan F1 terhadap penyakit hawar daun bakteri.

Penelitian bertujuan untuk mengetahui pertumbuhan dan ketahanan tanaman padi (Oryza sativa L.) hasil persilangan antara genotipe lokal dan IRBB-27 terhadap Hawar Daun Bakteri. 


\section{METODE PENELITIAN}

Penelitian ini dilaksanakan di Kebun Percobaan dan Laboratorium Penyakit Tumbuhan Tanaman serta Laboratorium Pemuliaan Tanaman Fakultas Pertanian Universitas Syiah Kuala, Darussalam Banda Aceh. Penelitian ini berlangsung dari bulan Februari sampai dengan bulan Juni 2016.

\section{MATERI DAN METODE}

Bahan-bahan yang digunakan adalah benih padi Sikuneng, Sigupai, IRBB27, benih padi hasil persilangan varietas Sigupai dengan IRBB-27 dan hasil persilangan varietas Sikuneng dengan IRBB-27, tanah, pupuk kandang, pupuk Urea, SP-36 dan $\mathrm{KCl}$, air serta isolat Xanthomonas oryzae pv. oryzae. Alat yang digunakan dalam penelitian ini adalah ember ( 75 buah), goni india (75 buah), pinset ( 2 buah), gunting ( 3 buah), jarum ose ( 2 buah), tabung reaksi (3 buah), petridish (10 buah), erlenmenyer ( 2 buah), kertas buram (10 lembar), timbangan analitik, thermometer, hygrometer meteran, cangkul, gembor, sprayer, kamera digital, label, spidol/pensil, rol dan buku pengamatan.

\section{Rancangan Percobaan}

Penelitian ini menggunakan Rancangan Acak Lengkap (RAL) non faktorial, dengan perlakuan genotipe dengan 5 taraf, diulang sebanyak 5 kali sehingga diperoleh 25 satuan percobaan. Setiap ulangan menggunakan 3 tanaman sehingga total tanaman yang diamati yaitu 75 tanaman.

\section{Metode Penelitian}

Pelaksanaan penelitian dimulai dengan mempersiapkan tempat penelitian. Seleksi benih yang ditanam, persiapan wadah penanaman yaitu ember berukuran $22 \times 35 \mathrm{~cm}$ dan persiapan media tanam berupa tanah lapisan topsoil dan pupuk kandang. Persiapan benih, Perendaman benih, perkecembahan benih dan persemaian benih. Persiapan media tanam tanah yang sudah disiapkan beserta pupuk kandang dicampur rata kemudian diaduk hingga tercampur (berlempur) perbandingan antara tanah dengan pupuk kandang adalah 2:1 dengan ukuran ember 8 liter. Penanaman dilakukan pada saat bibit padi beumur 10 hari setelah disemai, dalam ember persemaian dipindahkan ke ember budidaya. Bibit padi ditanam dengan kedalaman berkisar antara 0,5-2 cm. Setiap ember tanaman padi ditanam tiga bibit dan diberi air, setelah berumur 7 HST maka tanaman padi diseleksi lagi sehingga hanya tinggal satu yang dipelihara. Pemupukan, pupuk Urea diberikan sebanyak 3 kali, pupuk SP-36 diberikan satu kali dan pupuk $\mathrm{KCl}$ diberikan 2 kali. Pupuk Urea diberikan pada saat penanaman, pada 15 hari setelah tanam dan pada 30 hari setelah tanam. Pupuk SP-36 diberikan pada saat penanaman. Pupuk $\mathrm{KCl}$ diberikan pada saat penanaman dan 45 hari setelah tanam. Dosis pemberian pupuk yang diberikan adalah Urea $300 \mathrm{~kg} / \mathrm{ha}(1,2 \mathrm{~g}$ pot-1), untuk pupuk SP-36 $200 \mathrm{~kg} / \mathrm{ha}(0,8 \mathrm{~g}$ pot-1) dan untuk pupuk $\mathrm{KCl} 150 \mathrm{~kg} / \mathrm{ha}(0,6 \mathrm{~g}$ pot$1)$.

\section{Persiapan Bakteri Xanthomonas oryzae pv. oryzae}

Sumber inokulum diperoleh dari daerah tanaman padi yang terserang Xoo di Desa Lamtimpeung, Kecamatan Darussalam, Kabupaten Aceh Besar. Inokulum 
bakteri Xoo diisolasi dari daun tanaman padi yang terinfeksi Xoo, daun tanaman padi yang terinfeksi terlebih dahulu dibersihkan dari kotoran yang dicuci dengan air aquades. Daun tanaman padi yang terinfeksi Xoo dipotong

dengan ukuran $0,5 \times 0,5 \mathrm{~cm}$, selanjutnya daun tanaman padi direndam dalam alkohol $70 \%$ selama 2 menit dan dimasukkan kedalam air aqudes, daun tanaman padi yang sudah dipotong ditiriskan di atas tisue hingga air meresap. Potongan daun tanaman padi yang terinfeksi Xoo ditanam dalam media NA (Nutrient Agar). Setelah koloni bakteri tumbuh, diisolasi kembali untuk mendapatkan biakan murni.

\section{Uji Virulensi Bakteri}

Pegujian virulenlisasi Xoo dilakukan pada tanaman tembakau dengan cara koloni hawar daun bakteri hasil isolasi dalam kultur cair disuntikkan ke tulang daun tanaman tembakau. Sebagai kontrol, pada tulang daun tembakau lainnya disuntik dengan air aquades. Pengamatan gejala penyakit dilakukan 3-5 hari setelah penyuntikan dan difoto.

\section{Inokulasi Xanthomonas oryzae pv. oryzae}

Inokulasi Xoo dilakukan dengan cara koloni tunggal yang telah tumbuh diambil dengan menggunakan jarum ose steril dan dipindahkan ke media miring tabung reaksi, kemudian pembiakan dilakukan selama 2 × 24 jam. Untuk proses inokulasi, bakteri dicampur dengan air steril sebanyak $10 \mathrm{~mL}$ dengan konsentrasi bakteri $10^{8}$ sel $\mathrm{mL}^{-1}$ (diukur dengan menggunakan spektrofotometer). Inokulasi dilakukan pada semua tanaman (Sigupai, Sikuneng, IRBB-27 dan F1 keduanya) pada ujung daun. Daun tanaman padi digunting sebanyak 10 daun per rumpun. Pengguntingan dilakukan pada umur 42 hari setelah tanam.

Inokulasi bakteri Xoo dilakukan dengan metode pengguntingan pada ujung daun (Khaeruni et al., 2014). Dengan cara gunting dicelupkan kedalam suspensi Xoo yang telah diencerkan dan dilakukan pengguntingan $3-5 \mathrm{~cm}$.

\section{Pengamatan}

1. Pertumbuhan Tanaman

1.1 Tinggi tanaman $(\mathrm{cm})$

Pengamatan tinggi tanaman dilakukan setiap minggu dimulai pada umur 7 HST sampai pada umur 56 HST. Pengukuran dimulai dari pangkal batang diatas permukaan tanah sampai ujung daun tertinggi dengan cara meluruskan daun keatas.

\subsection{Jumlah anakan}

Pengamatan jumlah anakan dilakukan dengan menghitungkan jumlah anakan yang tumbuh dari batang padi utama, pengamatan dilakukan 3 hari sekali mulai umur 7 sampai 58 HST.

\subsection{Umur berbunga padi (hari)}

Pengamatan umur berbunga dilakukan pada saat tanaman berbunga setelah tanam dengan cara melihat tanaman yang akan muncul bunganya pada hari berapa setelah tanam. 


\section{Xanthomonas oryzae pv. Oryzae}

\subsection{Masa Inkubasi (hari)}

Masa inkubasi adalah waktu antara permulaan infeksi dengan timbulnya gejala yang pertama. Gejala dari Xoo pada tanaman padi dapat dilihat beberapa kriteria yang akan timbul pada daun tanaman padi seperti: layu, kuning pucat dan kering.

\subsection{Panjang Lesio $(\mathrm{cm})$}

Pengamatan panjang lesio dilakukan pada umur 7 dan 14 hari setelah inokulasi (HSI), dengan mengukur panjang lesio dari 10 daun per rumpun.

\subsection{Intensitas Serangan (\%)}

Pada saat pengukuran lesio daun diukur juga panjang keseluruhan daun, agar dapat dihitung persentase serangan Xoo. Intensitas serangan dihitung dengan menggunakan rumus:

$$
\text { Intesitas Serangan }=\frac{\text { Panjang Lesio Xoo }(\mathrm{cm})}{\text { Panjang Daun Keseluruhan }(\mathrm{cm})} \text { X } 100 \%
$$

\section{Suhu dan kelembaban (\%)}

Pengamatan suhu dan kelembaban diukur dengan alat pengukur suhu yaitu alat termometer dan hygrometer untuk alat mengukur kelembaban, dimana alat pengukur suhu dan kelembaban diletakkan dalam lokasi budidaya tanaman padi, pemantauan suhu dan kelembaban selalu dilihat setiap hari dan dicatat perubahannya. Pengamatan ini hanya dilakukan mulai saat inokulasi Xoo sampai dengan hari terakhir pengamatan (14 HSI).

\section{HASIL DAN PEMBAHASAN}

\section{Tinggi Tanaman $(\mathbf{c m})$}

Tabel 1. Rata-rata tinggi tanaman (cm) pada umur 7, 14, 21, 28, 35, 42, 49 dan 56 HST

\begin{tabular}{lcccccccc}
\hline \multirow{2}{*}{ Perlakuan } & \multicolumn{7}{c}{ Tinggi tanaman $(\mathrm{cm})$} \\
\cline { 2 - 9 } & 7 & 14 & 21 & 28 & 35 & 42 & 49 & 56 \\
\hline Sigupai & $27,86 \mathrm{ab}$ & $39,51 \mathrm{ab}$ & $50,95 \mathrm{a}$ & $64,67 \mathrm{a}$ & $80,69 \mathrm{a}$ & $104,18 \mathrm{ab}$ & $123,65 \mathrm{~b}$ & $133,38 \mathrm{~b}$ \\
Sikuneng & $29,73 \mathrm{bc}$ & $43,98 \mathrm{ab}$ & $54,58 \mathrm{ab}$ & $68,65 \mathrm{a}$ & $82,81 \mathrm{a}$ & $111,19 \mathrm{bc}$ & $127,85 \mathrm{~b}$ & $143,22 \mathrm{~b}$ \\
IRBB-27 & $26,42 \mathrm{a}$ & $38,42 \mathrm{a}$ & $48,35 \mathrm{a}$ & $64,51 \mathrm{a}$ & $81,16 \mathrm{a}$ & $92,95 \mathrm{a}$ & $98,67 \mathrm{a}$ & $108,05 \mathrm{a}$ \\
F1 (Sg/IRBB-27) & $31,09 \mathrm{~cd}$ & $44,60 \mathrm{~b}$ & $58,91 \mathrm{~b}$ & $80,12 \mathrm{~b}$ & $97,93 \mathrm{~b}$ & $116,72 \mathrm{~cd}$ & $129,39 \mathrm{~b}$ & $142,40 \mathrm{~b}$ \\
F1 (Sk/IRBB-27) & $32,16 \mathrm{~d}$ & $55,21 \mathrm{c}$ & $67,57 \mathrm{c}$ & $92,32 \mathrm{c}$ & $113,12 \mathrm{c}$ & $127,64 \mathrm{~d}$ & $137,25 \mathrm{~b}$ & $145,93 \mathrm{~b}$ \\
\hline Nilai BNT 0,05 & 2,05 & 5,84 & 7,60 & 8,27 & 9,10 & 12.43 & 15,26 & 14,46 \\
\hline Keterangan: Angka yang diikuti oleh huruf yang sama pada kolom yang sama tidak berbeda nyata pada taraf $5 \%(\mathrm{Uji}$ BNT 0,05$)$.
\end{tabular}

Pertumbuhan tinggi tanaman ditentukan oleh faktor biotik dan abiotik, keadaan lingkungan disekitar yang bervariasi sehingga ada genotipe yang tidak sesuai dengan kondisi tumbuh (Vaughan, 1994) menambahkan bahwa perbedaan tinggi tanaman dipengaruhi oleh kondisi lingkungan disekitar. Selain faktor lingkungan pertumbuhan tinggi tanaman ditentukan oleh faktor genetik yang dimiliki oleh masing-masing genotipe yang dapat menyebabkan perbedaan tinggi tanaman antara satu genotipe dengan genotipe yang lain. Tanaman padi yang 
memiliki batang pendek diduga memiliki gen sd-1 (semi dwarf gene). Tanaman yang mengandung gen sd-1 akan memiliki tinggi tanaman yang relatif rendah, karena gen sd-1 merupakan gen yang mereduksi kadar giberelin (hormon yang mengatur pertumbuhan tanaman) (Ito et al., 2002).

Hasil kedua F1 (Sg/IRBB-27 dan Sk/IRBB-27) menunjukkan tinggi tanaman mencapai 142,40 dan $145,93 \mathrm{~cm}$ yang dapat menyebabkan tanaman tidak tahan terhadap rebahan (tabel 1). Menurut Kustera (2008) semakin tinggi tanaman maka semakin berat bobot pangkal batang yang terbebani sehingga tanaman tidak tahan terhadap rebahan. Jika tanaman padi terlalu pendek mudah terserang hama dan penyakit karena daunnya dapat menyentuh tanah. Khush (1997) menyatakan bahwa jika tanaman padi memiliki batang pendek dapat mengurangi respirasi sehingga baik untuk keseimbangan fotosintesis-respirasi. Dalam ilmu pemuliaan tanaman, padi yang memiliki batang tinggi sangat berpotensi untuk dijadikan tetua dalam melakukan persilangan untuk menghasilkan benih hibrida (Ridho, 2011). Menurut Swasti et al., (2008) menyatakan bahwa tinggi tanaman padi yang ideal berkisar antara 90-100 cm dijadikan sebagai tinggi tanaman ideal untuk mendapatkan hasil maksimum.

\section{Jumlah Anakan Per Rumpun}

Tabel 2. Rata-rata jumlah anakan pada umur 7, 10, 13, 16, 19, 22, 25, 28, 31 dan 34 HST

\begin{tabular}{lcccccccccc}
\hline \multirow{2}{*}{ Perlakuan } & \multicolumn{10}{c}{ Tinggi tanaman $(\mathrm{cm})$} \\
\cline { 2 - 9 } Sigupai & 7 & 10 & 13 & 16 & 19 & 22 & 25 & 28 & 31 \\
Sikuneng & $1,47 \mathrm{ab}$ & $1,60 \mathrm{a}$ & $2,60 \mathrm{a}$ & $2,67 \mathrm{a}$ & $2,80 \mathrm{a}$ & $3,27 \mathrm{a}$ & $3,33 \mathrm{a}$ & $3,40 \mathrm{a}$ & $3,73 \mathrm{a}$ & $4,00 \mathrm{a}$ \\
IRBB-27 & $1,00 \mathrm{a}$ & $1,53 \mathrm{a}$ & $2,33 \mathrm{a}$ & $2,53 \mathrm{a}$ & $2,80 \mathrm{a}$ & $3,13 \mathrm{a}$ & $3,47 \mathrm{a}$ & $3,80 \mathrm{a}$ & $4,13 \mathrm{a}$ & $4,47 \mathrm{a}$ \\
F1 (Sg/IRBB-27) & $1,87 \mathrm{bc}$ & $2,67 \mathrm{~b}$ & $5,00 \mathrm{c}$ & $5,20 \mathrm{c}$ & $6,33 \mathrm{c}$ & $8,53 \mathrm{c}$ & $10,13 \mathrm{c}$ & $10,73 \mathrm{c}$ & $11,13 \mathrm{c}$ & $11,20 \mathrm{c}$ \\
F1 (Sk/IRBB-27) & $2,13 \mathrm{c}$ & $2,73 \mathrm{~b}$ & $3,80 \mathrm{~b}$ & $4,07 \mathrm{~b}$ & $4,40 \mathrm{~b}$ & $5,80 \mathrm{~b}$ & $7,00 \mathrm{~b}$ & $8,20 \mathrm{~b}$ & $8,87 \mathrm{bc}$ & $9,07 \mathrm{bc}$ \\
& $2,00 \mathrm{bc}$ & $2,53 \mathrm{~b}$ & $4,33 \mathrm{~b}$ & $4,47 \mathrm{~b}$ & $5,07 \mathrm{bc}$ & $7,20 \mathrm{bc}$ & $7,80 \mathrm{~b}$ & $8,07 \mathrm{~b}$ & $8,07 \mathrm{~b}$ & $8,07 \mathrm{~b}$ \\
\hline Nilai BNT 0,05 & 0,53 & 0,52 & 0,80 & 0,85 & 1,30 & 1,44 & 2,02 & 2,20 & 2,39 & 2,59 \\
\hline Keterangan: Angka yang diikuti oleh huruf yang sama pada kolom yang sama tidak berbeda nyata pada taraf $5 \%(\mathrm{Uji}$ BNT
\end{tabular}

Tabel 3. Rata-rata jumlah anakan pada umur, $37,40,43,46,49,52,55$ dan 58HST

\begin{tabular}{lcccccccc}
\hline \multirow{2}{*}{ Perlakuan } & \multicolumn{7}{c}{ Tinggi tanaman $(\mathrm{cm})$} \\
\cline { 2 - 8 } Sigupai & 37 & 40 & 43 & 46 & 49 & 52 & 55 & 58 \\
Sikuneng & $4,27 \mathrm{a}$ & $4,33 \mathrm{a}$ & $4,53 \mathrm{a}$ & $4,53 \mathrm{a}$ & $4,53 \mathrm{a}$ & $4,60 \mathrm{a}$ & $4,73 \mathrm{a}$ & $4,73 \mathrm{a}$ \\
IRBB-27 & $4,67 \mathrm{a}$ & $4,73 \mathrm{a}$ & $4,80 \mathrm{a}$ & $4,87 \mathrm{a}$ & $4,87 \mathrm{a}$ & $4,87 \mathrm{a}$ & $4,87 \mathrm{a}$ & $4,87 \mathrm{a}$ \\
F1 (Sg/IRBB-27) & $11,33 \mathrm{c}$ & $11.40 \mathrm{c}$ & $11,47 \mathrm{c}$ & $11,47 \mathrm{c}$ & $11,47 \mathrm{c}$ & $11,47 \mathrm{c}$ & $11,73 \mathrm{c}$ & $11,80 \mathrm{c}$ \\
F1 (Sk/IRBB-27) & $9,33 \mathrm{bc}$ & $9,47 \mathrm{bc}$ & $9,80 \mathrm{bc}$ & $9,80 \mathrm{bc}$ & $9,80 \mathrm{bc}$ & $10,00 \mathrm{bc}$ & $10,20 \mathrm{bc}$ & $10,27 \mathrm{bc}$ \\
& $8,13 \mathrm{~b}$ & $8,33 \mathrm{~b}$ & $8,33 \mathrm{~b}$ & $8,33 \mathrm{~b}$ & $8,33 \mathrm{~b}$ & $8,33 \mathrm{~b}$ & $8,47 \mathrm{~b}$ & $8,60 \mathrm{~b}$ \\
\hline Nilai BNT 0,05 & 2,62 & 2,75 & 2,80 & 2,79 & 2,79 & 2,86 & 2,79 & 2,73 \\
\hline Keterangan: Angka yang diikuti oleh huruf yang sama pada kolom yang sama tidak berbeda nyata pada taraf 5\% (Uji BNT & $70.05)$
\end{tabular}

Jumlah anakan (tabel 2 dan 3) genotipe IRBB-27 lebih tinggi dibandingkan dengan jumlah anakan genotipe lain yang diteliti, jumlah anakan genotipe IRBB27 terus meningkat pada umur 13 sampai 31 HST, rata-rata jumlah anakan varietas IRBB-27 umur 31 HST yaitu 11,13 batang. Sedangkan pada umur 43 sampai 52 HST jumlah anakan varietas IRBB-27 tidak mengalami penambahan dengan rata-rata jumlah anakan 11,47 batang. Pertambahan jumlah anakan 
genotipe IRBB-27 berhenti pada saat umur tanaman padi 58 HST dengan rata-rata jumlah anakan 11,80 .

Kedua hasil F1 menunjukkan jumlah anakan yang banyak jika dibandingkan dengan genotipe Sigupai dan Sikuneng. F1 (Sg/IRBB-27) pertambahan jumlah anakan terus meningkat hingga sampai umur 58 HST. Rata-rata jumlah anakan F1 (Sg/IRBB-27) pada umur ke 58 HST yaitu 10,27 batang, jika dibandingkan dengan genotipe Sigupai rata-rata jumlah anakan pada umur 58 yaitu 4,73 batang. Hasil F1 (Sk/IRBB-27) jumlah anakan terus bertambah sampai umur 28 HST ratarata jumlah anakan yaitu 8,67. Pertambahan jumlah anakan F1 (Sk/IRBB-27) melemah pada umur 31 sampai 58 HST.

Perbedaan jumlah anakan disetiap genotipe yang dihasilkan per rumpunn disebabkan oleh faktor genetik dan lingkungan. Tidak semua genotipe menghendaki lingkungan yang sama. Hal ini sejalan dengan penelitian Alridiwirsah et al., (2015) yang menyatakan bahwa jumlah anakan juga dipengaruhi oleh tingginya temperatur, pada temperatur tinggi jumlah anakan yang terbentuk lebih banyak.

\section{Umur Berbunga (hari)}

Tabel 4. Rata-rata umur berbunga (hari)

\begin{tabular}{lc}
\hline Perlakuan & Umur berbunga (hari) \\
\hline Sigupai & $104,33 \mathrm{~d}$ \\
Sikuneng & $111,93 \mathrm{e}$ \\
IRBB-27 & $64,20 \mathrm{~b}$ \\
F1 (Sg/IRBB-27) & $73,07 \mathrm{c}$ \\
F1 (Sk/IRBB-27) & $61,47 \mathrm{a}$ \\
\hline Nilai BNT 0,05 & 2,19
\end{tabular}

\section{Keterangan: Angka yang diikuti oleh huruf yang sama pada kolom yang sama tidak berbeda nyata pada taraf $5 \%$ (Uji $\mathrm{BNT}_{0,05}$ ).}

Tabel 4 menunjukkan bahwa rata-rata umur berbunga tercepat terdapat pada F1 (Sk/IRBB-27) yang berbeda nyata dengan umur berbunga genotipe lainnya yang diteliti. Sedangkan umur berbunga terlama terdapat pada genotipe Sikuneng yang berbeda nyata dengan umur berbunga genotipe lain yang diteliti.

\section{Masa Inkubasi (hari)}

Masa inkubasi (tabel 5) merupakan gejala awal yang timbul pada daun padi setelah inokulasi Xoo yang ditandai dengan daun menjadi kuning dari ujung bekas pengguntingan, terdapat bercak dari pinggir daun, hingga daun menguning. Dari pengamatan diatas semua genotipe yang diteliti menunjukkan gejala awal dari penyakit HDB berkisar 2-6 hari setelah inokulasi. Lama atau cepatnya gejala awal yang ditimbulkan oleh HDB sangat tergantung pada tingkat virulensi bakteri tersebut. Ini sejalan dengan penelitian Rahim et al., (2012) yang menyatakan bahwa masa inkubasi sangat berpengaruh terhadap tingkat virulensi dari bakteri 
Xoo, semakin tinggi virulensi bakteri maka semakin singkatnya waktu munculnya gejala. Jika tanaman tahan terhadap bakteri Xoo maka semakin panjang masa inkubasi. Semakin panjang masa inkubasi berpengaruh secara tidak langsung terhadap intensitas serangan penyakit hawar daun bakteri pada tanaman (Djatmiko dan Fatichin, 2009).

Tabel 5. Rata-rata masa inkubasi (hari) penyakit hawar daun bakteri

\begin{tabular}{lc}
\hline Perlakuan & Masa inkubasi (hari) \\
\hline Sigupai & $3,21 \mathrm{a}$ \\
Sikuneng & $3,23 \mathrm{a}$ \\
IRBB-27 & $4,37 \mathrm{~b}$ \\
F1 (Sg/IRBB-27) & $3,20 \mathrm{a}$ \\
F1 (Sk/RBB-27) & $3,23 \mathrm{a}$ \\
\hline Nilai BNT 0,05 & 0,11
\end{tabular}

Keterangan: Angka yang diikuti oleh huruf yang sama pada kolom yang sama tidak berbeda nyata pada taraf $5 \%\left(\mathrm{Uji}_{\mathrm{BNT}} \mathrm{BN}_{0,05}\right)$.

\section{Panjang Lesio (cm)}

Tabel 6. Rata-rata panjang lesio (cm) Hawar Daun Bakteri pada hari ke 7 dan 14 setelah inokulasi

\begin{tabular}{lcc}
\hline \multirow{2}{*}{ Perlakuan } & \multicolumn{2}{c}{ Panjang lesio $(\mathrm{cm})$} \\
\cline { 2 - 3 } Sigupai & $7 \mathrm{HSI}$ & $6,14 \mathrm{HSI}$ \\
Sikuneng & $0,18 \mathrm{bc}$ \\
IRBB-27 & $0,12 \mathrm{a}$ & $2,70 \mathrm{~b}$ \\
F1 (Sg/IRBB-27) & $0,20 \mathrm{c}$ & $0,49 \mathrm{a}$ \\
F1 (Sk/IRBB-27) & $0,17 \mathrm{~b}$ & $0,34 \mathrm{a}$ \\
\hline Nilai BNT 0,05 & $0,21 \mathrm{c}$ & $0,67 \mathrm{a}$ \\
\hline
\end{tabular}

Keterangan: Angka yang diikuti oleh huruf yang sama pada kolom yang sama tidak berbeda nyata pada taraf $5 \%\left(\mathrm{Uji} \mathrm{BNT}_{0,05}\right)$.

Panjang lesio (tabel 6) pada ke 5 genotipe yang diteliti yang sangat beragam. Dilihat pada tabel 6 bahwa genotipe Sigupai dan Sikuneng lebih tahan terhadap Xoo pada hari ke 7 dibandingkan dengan genotipe IRBB-27. Dilihat pada hari ke 14 genotipe Sigupai lebih rentan dibandingkan dengan varietas IRBB-27 dengan rata-rata panjang lesio mencapai $6,42 \mathrm{~cm}$. Pada hari 8 sampai 14 setelah inokulasi (SI) perkembangan Xoo terhambat pada genotipe IRBB-27 karena genotipe tersebut tahan terhadap HDB. Sedangkan genotipe Sigupai terus berlangsung hingga sampai 14 hari setelah inokulasi, karena genotipe terssebut tidak tahan terhadap Xoo. 


\section{Intensitas Serangan (\%)}

Dari semua genotipe yang diteliti menunjukkan rata-rata intensitas serangan dibawah 10\%, kecuali genotipe Sigupai dengan nilai rata-rata intensitas serangan mencapai 11,15\% (tabel 7). Dari data tersebut dapat disimpulkan bahwa semua varietas tahan terhadap penyakit hawar daun bakteri, kecuali genotipe Sikuneng yang rentan terhadap HDB. Menurut Yoshitula et al., (1997) kriteria intensitas serangan $\mathrm{T}=$ tahan (intensitas serangan $<10 \%$ ), $\mathrm{P}=$ peka (intensitas serangan $>10 \%)$.

Tabel 7. Rata-rata intensitas serangan (\%) penyakit hawar daun bakteri pada 7 dan 14 HSI

\begin{tabular}{lccc}
\hline \multirow{2}{*}{ Perlakuan } & \multicolumn{3}{c}{ Intensitas penyakit (\%) } \\
\cline { 2 - 4 } & \multicolumn{3}{c}{ 14 HSI } \\
\hline Sigupai & $0,32 \mathrm{c}$ & 11,15 & $3,33 \mathrm{c}$ \\
Sikuneng & $0,24 \mathrm{a}$ & 5,06 & $2,13 \mathrm{~b}$ \\
IRBB-27 & $0,36 \mathrm{c}$ & 0,86 & $0,93 \mathrm{a}$ \\
F1 (Sg/IRBB-27) & $0,24 \mathrm{ab}$ & 0,49 & $0,70 \mathrm{a}$ \\
F1 (Sk/IRBB-27) & $0,30 \mathrm{bc}$ & 0,91 & $0,92 \mathrm{a}$ \\
\hline Nilai BNT 0,05 & 0,06 & & 0,51
\end{tabular}

Keterangan: Angka yang diikuti oleh huruf yang sama pada kolom yang sama tidak berbeda nyata pada taraf $5 \%\left(\mathrm{Uji}_{\mathrm{BNT}} \mathrm{BN}_{0.05}\right)$.

Perbedaan intensitas serangan penyakit HBD pada masing-masing genotipe yang diteliti pada tabel 7 yang terendah dijumapai pada F1 (Sk/IRBB-27) sedangkan yang tertinggi dijumpai pada genotipe Sigupai. Perbedaan intensitas serangan HBD diduga tanaman memiliki faktor genetik yang tahan terhadap serangan HBD. Ini sejalan pendapat Suryadi dan Kadir (2009) yang menyatakan perbedaan intensitas serangan HBD selain ditentukan oleh virulensi dari patogen juga dipengaruhi oleh tingkat ketahanan tanaman terhadap HBD yang ditentukan oleh faktor genetik. Intensitas serangan hawar daun bakteri juga ditentukan oleh umur tanaman padi, umur padi yang muda akan mudah terinfeksi penyakit HDB karena daun tanaman padi belum begitu keras. Ini sejalan dengan penelitian Khaeruni et al., (2014) yang menyatakan bahwa fase pertumbuhan dan genotipe padi berpengaruh terhadap perkembangan penyakit HDB semakin muda fase pertumbuhan tanaman saat terinfeksi maka semakin cepat perkembangan penyakitnya.

Selain fase pertumbuhan intensitas serangan HDB sangat ditentukan tingkat virulensi dari bakteri tersebut yang ditentukan oleh 3 komponen yaitu patogen, inang dan lingkungan biotik dan abiotik (Yuriyah et al., 2013). Dari hasil penelitian dapat dilihat bahwa kedua $\mathrm{F} 1$ tahan terhadap penyakit HDB dengan rata-rata intensitas serangan $\mathrm{F} 1$ (Sg/IRBB-27) 0,49 \%, sedangkan F1 (Sk/IRBB27) rata-rata intensitas serangan adalah $0,91 \%$. Suhu juga berpangruh sangat penting terhadap virulensi HDB, suhu lingkungan yang optimal bagi perkembangan penyakit $\mathrm{HDB}$ adalah $30^{\circ} \mathrm{C}$ (Wiyono, 2007). Pada saat inokulasi suhu harian berkisar antara $29-32^{\circ} \mathrm{C}$ ini sangat mendukung tingkat virulensi 
bakteri HDB. Pertumbuhan bakteri akan terhambat jika suhu mencapai lebih dari $38^{\circ} \mathrm{C}$ dan akan menurun tingkat virulensi dari penyakit HDB (Xanthomonas oryzae pv. oryzae).

\section{KESIMPULAN DAN SARAN}

\section{KESIMPULAN}

Hasil persilangan F1 (Sk/IRBB-27) tahan terhadap Xoo dan umur berbunga yang cepat yaitu 61,467 HST tetapi memiliki batang yang sangat tinggi dari ke 5 genotipe dan dengan jumlah anakan yang masih tergolong dalam kriteria sedikit dan genotipe yang tidak tahan terhadap penyakit hawar daun bakteri adalah genotipe Sigupai dengan rata-rata intensitas serangan mencapai $11,15 \%$.

\section{SARAN}

Berdasarkan hasil penelitian maka perlu dilakukan perbaikan untuk genotipe F1 (Sg/IRBB-27) dan F1 (Sk/IRBB-27) terhadap tinggi tanaman, jumlah anakan dengan cara disilangkan dengan genotipe yang memiliki tinggi tanaman yang pendek dan jumlah anakan yang banyak, sehingga akan didapatkan tinggi tanaman dan jumlah anakan yang ideal.

\section{UCAPAN TERIMA KASIH}

Syukur Alhamdulillah penulis panjatkan kehadirat Allah Swt. yang telah memberikan Rahmat dan Hidayah-Nya kepada Penulis, sehingaa penulis dapat menyelesaikan penulisan Jurnal Ilmiah Mahasiswa dengan judul "Uji Tanaman Padi Hasil Persilangan Varietas Lokal dengan IRBB-27 terhadap Pertumbuhan dan Ketahanan Hawar Daun Bakteri". Shalawat dan salam penulis panjatkan kepada keharibaan Nabi Muhammad Saw.

Dalam kesempatan ini penulis ingin mengucapkan terima kasih yang sebesar-besarnya kepada Ayahanda dan Ibunda tercinta serta kakak dan adik yang telah mendoakan dan memberi semangat serta motivasi kepada penulis sehingga penulis dapat menyelesaiakn penulisan Jurnal Ilmiah Mahasiswa ini. Pada kesempatan ini penulis juga menyampaikan ucapan terima kasih yang sebesarbesarnya kepada: Bapak Dr. Bakhtiar, S.P., M.Si. sebagai pembimbing utama dan Ibu Ir. Hj. Cut Nur Ichsan, M.P. sebagai pembimbing anggota dalam penelitian ini yang telah banyak memeberikan arahan serta bimbingan yang luar biasa besarnya sehingga penulis dapat menyelesaikan dan memahami isi dari karya ilmiah ini.

Bapak Dr. Ir. Syamsuddin, M.Si selaku ketua Prodi Agroteknologi dan ibu Dr. Rita Hayati, S.P., M.Si selaku sekretaris Prodi Agroteknologi yang membantu penulis dalam hal penngesahan administrasi. Serta kepada kak Zaleha, S.E dan kak Siti, S.Pt yang membantu penulis dalam pengurusan kelengkapan andministrasi.

\section{DAFTAR PUSTAKA}

Alridiwirsah, Hamidah, H., Erwin, M. H., dan Muchtar Y. (2015). Uji Toleransi Beberapa Varietas Padi (Oryza sativa L.) Terhadap Naungan. Jurnal Pertanian Tropik. 2 (12) : 93-101. 
CAB International. 2005. Crop Protection Compendium. Wallingford, UK. CDROM.

Djatmiko, H. A \& Fatichin. 2009. Ketahanan Dua Puluh Satu Varietas Padi Terhadap Penyakit Hawar Daun Bakteri. J. HPT. 9 (2) : 168-173.

Ito, H., M. Ueguchi., T. Sakamoto., T. Kayano., H. Tanaka, M. Ashikari \& M Matsuoka, 2002. Modification of Plant Height by Supressing the HeigthControling Gene, D-18, in Rice. Breeding Sciences 52:215-218.

Iyer-Pascuzzi, A.S. and S.R. McCouch. 2007. Recessive resistance genes and the Oryza sativa-Xanthomonas oryzae pv. oryzae pathosystem. Molecular Plant Microbe Interaction 20 (7):731-739.

Kadir, T.S., I. Hanarida, D.W. Utami, S. Koerniati, A.D. Ambarwati, A. Apriana, dan S. Sisharmini. 2007. Evaluasi ketahanan populasi haploid ganda silangan IR64 dan Oryza rufipogon terhadap hawar dan bakteri pada stadia bibit. Bul. Plasma Nutfah.

Khaeruni, A., Taufik, M., Teguh Wijayanto dan Eko Aprianto Johan. 2014. Perkembangan Penyakit Hawar Daun Bakteri pada Tiga Varietas Padi Sawah yang Diinokulasi pada Beberapa Fase Pertumbuhan. Fitopatologi Indonesia, 10 (4), pp. 119-125.

Nayak, D., M.L. Shanti, L.K. Bose, U.D. Singh, and P. Nayak. 2008. Pathogenicity association in Xanthomonas oryzae pv. oryzae the caosal organism of rice bacterial blight disease. Asian Research Publishing Network (ARPN). J. Agric. Biol. Sci. 3 (1):12-27.

Rahim, A., Khaeruni A. R. \& Taufik, M. 2012. Reaksi Ketahanan Beberapa Varietas Padi Komersial Terhadap Patotipe Xanthomonas oryzae pv. oryzae Isolat Sulawesi Tenggara. Berakala Penelitian Agronomi. 1 (2) : 132-138.

Ridho, F. 2011. Identifikasi karakter agronomis varietas padi (Oryzae sativa L.) lokal Aceh selama masa vegetatif. Skripsi. Jurusan Budidaya Pertanian. Fakultas Pertanian Universitas Syiah Kuala. Banda Aceh.

Sitaresmi T., R. H. Wening, A. T. Rakhmi, N. Yunani dan U. Susanto. 2013. Pemanfaatan Plasma Nutfah Padi Varietas Lokal dalam Perakitan Varietas Unggul. IPTEK Tanaman Pangan. 8. 1.

Sudaryanto. T., D.K.S. Swastika. B. Sayaka. and S. Bahri. 2006. Financial and Economic Profitability of Rice Farming Across Production Environments in Indonesia. Paper presented at the International Rice Congress 2006. 9-13 Oct 2006 in New Delhi. India.

Swasti E, Syarif, A. A., Irfan S, Nurwanita EP, Sri M, dan Novita S. 2008. Eksplorasi dan Identifikasi Sumberdaya Genetik Tanaman Padi Lokal di Kabupaten Solok Selatan Provinsi Sumatra Barat : Prosiding Seminar Bidang Ilmu Pertanian BKS PTN Wilayah Barat Banda Aceh.

Tasliah. 2012. Gen Ketahanan Tanaman Padi Terhadap Bakteri Hawar Daun (Xanthomonas oryzae pv. oryzae). J. Litbang Pert. 31 (3) : 103-112.

Triny SK, Suryadi Y, Sudir, \& Machmud M. 2011. Penyakit Bakteri Padi dan Cara Pengendaliannya. Bogor: Balai Besar Penelitian Tanaman Padi.

Vaughan, D. A. 1994. The Wild Relatives of Rice. A genetic Resources Handbook. International Rice Research Institute. Manila, Philippines.

Wibowo, B.S. 2002. Pengamatan, Peramalan dan Pengendalian Penyakit Hawar Daun Bakteri (Xanthomonas campestris pv. oryzae). Makalah dalam 
Pelatihan Pengamatan, Peramalan dan Pengendalian Organisme Pengganggu Tanaman Pangan. Jatisari, 16-27 September 2002. BPOPT Jatisari.

Winandari, O. P., A. Tjahjoleksono dan D. W. Utami. 2014. Identifikasi Marka Gen Ketahanan Hawar Daun Bakteri pada Galur Padi Introduksi dan Galur Dihaploid. J. HPT Tropika. 14 (2) : 101-109.

Wiyono, S. 2007. Perubahan iklim dan ledakan hama dan penyakit tanaman. Makalah Seminar Keanekaragaman Hayati Ditengah Perubahan Iklim.

Yashitola, J., D. Krishnaveni, A.P.K. Reddy, and R.V. Sonti. 1997. Genetic diversity within the population of $X$. oryzae pv. oryzae in India. Phytopathology. 87:760 -765.

Yuriyah, S. Utami D. W. \& Hanarida, I. 2013. Uij Ketahanan Galur-galur Harapan Padi terhadap Penyakit Hawar Daun Bakteri (Xanthomonas oryzae pv. oryzae) Ras III, IVdan VIII. Buletin Plasma Nutfah. 19 (2): 5360 . 